\title{
TINGKAT KERAWANAN KEBAKARAN GAMBUT DI KABUPATEN MUSI BANYUASIN, SUMATERA SELATAN
}

\author{
Peat Fire Susceptibility in Musi Banyuasin District, South Sumatra \\ Hesti Lestari Tata ${ }^{1 *}$, Budi Hadi Narendra ${ }^{1}$ dan/and Mawazin ${ }^{1}$ \\ ${ }^{1}$ Pusat Penelitian dan Pengembangan Hutan, Jalan Gunung Batu 5, Bogor, Jawa Barat, Indonesia, \\ Telp.: +62-251-8633234 \\ *Penulis korespondensi, Email: hl.tata@gmail.com
}

Tanggal diterima: 9 Feberuari 2017; Tanggal direvisi: 18 Mei 2017; Tanggal disetujui: 22 Juni 2017

\begin{abstract}
Forest and land fire in 2015 was a catastrophe in Indonesia, as it did not only cause damage on forest ecosystem and environments, but also impacted human health and economic loss. This research aimed to identify hotspots distribution in 2014-2015 as an indicator of forest and land fire, and to analyze fire susceptibility in Musi Banyuasin district, South Sumatra. Data used for fire prone analysis consisted of land cover map, forest status, hotspots data derived from NOAA18, soil types, topography and moratorium map. Results showed that based on land function, hotspots were mostly found in production forest with hotspots density of 0.049 hotspots $\mathrm{km}^{-2}$. Based on land cover type, hotspots were mostly found in the open land (88 hotspots). Based on soil types, hotspots were mostly occurred on peat soils (180 hotspots and hotspot density 0.048 hotspot $\mathrm{km}^{-2}$ ). Soil type was mostly associated with hotspot occurrence. Sub-district of Bayung Lencir has the highest fire susceptibility among others. Low precipitation and El-Ninö phenomenon in 2015 were not the only drivers of peat fire. However two main current problems in the Forest Management Unit of Lalan Mangsang Mendis (e.g. illegal logging and open access) were driver factors of peat fire in the district.
\end{abstract}

Key words: Fire prevention, fire risk map, forest management unit (FMU), peatland, spatial analysis

\begin{abstract}
ABSTRAK
Kebakaran lahan dan hutan tahun 2015 telah menjadi bencana karena tidak hanya menyebabkan kerusakan pada kerusakan ekosistem hutan dan lingkungan, tetapi juga kerugian ekonomi dan kesehatan manusia. Penelitian ini bertujuan untuk mengidentifikasi sebaran titik panas tahun 2014-2015 sebagai indikator kebakaran dan menganalisis tingkat kerawanan kebakaran gambut di Kabupaten Musi Banyuasin, Sumatera Selatan. Data yang digunakan sebagai faktor penyusunan tingkat kerawanan adalah data spasial tutupan lahan, status kawasan, data titik panas hasil olahan dari citra NOAA18, peta tipe tanah, peta rupa bumi Indonesia dan peta moratorium gambut. Hasil analisis tahun 2015 menunjukkan bahwa berdasarkan fungsi kawasan, jumlah hotspot terbanyak dijumpai di hutan produksi (HP), yaitu 196 hotspot dengan kepadatan hotspot sebesar 0.049 hotspot $\mathrm{km}^{2}$. Berdasarkan tipe tutupan lahan, jumlah hotspot terbesar dijumpai pada lahan terbuka sebanyak 83 hotspot. Berdasarkan tipe tanah, hotspot yang dijumpai pada lahan gambut sebanyak 180 titik, dengan kepadatan 0.048 hotspot $\mathrm{km}^{2}$. Dengan menggunakan empat faktor penyebab yang paling berpengaruh terhadap kebakaran hutan dan lahan, maka faktor lahan gambut merupakan faktor yang paling berpengaruh terhadap kebakaran. Tingkat kerawanan kebakaran paling tinggi terjadi di Kecamatan Bayung Lencir. Fenomena El-Nino tahun 2015 bukan penyebab utama kejadian kebakaran gambut, tetapi masih maraknya illegal logging dan 'open access' area yang menjadi masalah utama pada Kesatuan Pengelolaan Hutan Lalan Mangsang Mendis menjadi faktor pemicu terjadinya kebakaran gambut di kabupaten ini.
\end{abstract}

Kata kunci: Gambut, kesatuan pengelolaan hutan, pencegahan kebakaran, rawan kebakaran, spasial 


\section{PENDAHULUAN}

Luas lahan gambut Indonesia tercatat seluas 14,85 juta ha (Wahyunto, Nugroho, Ritung, \& Sulaeman, 2014), sedangkan luas lahan gambut terdegradasi tidak produktif di Indonesia dilaporkan seluas 4,2 juta ha (BBSDLP, 2013). Setelah kejadian kebakaran tahun 2015, luas hutan rawa gambut terdegradasi meningkat tajam. Hutan dan lahan gambut memiliki tipe ekosistem yang khas, karena kandungan bahan organiknya yang tinggi. Pada kondisi alami, gambut jenuh akan air. Tetapi pada kondisi gambut terdegradasi akibat pembukaan hutan, pembuatan drainase, air gambut akan dengan mudah mengalir keluar, sehingga gambut menjadi kering (Turetsky et al., 2015; Taufik, Setiawan, \& Lanen, 2015). Bahan organik pada kondisi ke-ring dan saat kemarau panjang akan sangat mudah terbakar. Sebagian besar kejadian kebakaran hutan dan lahan gambut disebabkan oleh manusia (anthropogenic) (Page \& Hooijer, 2016; Cattau et al., 2016).

Dampak kebakaran hutan dan lahan berpengaruh secara langsung dan tidak langsung terhadap manusia dan lingkungannya baik di dalam negeri maupun luar negeri (Marlier, Defries, Kim, Koplitz, \& Jacob, 2015; Marlier, Defries, Pennington, \& Nelson, 2015; Turetsky et al., 2015). Kebakaran pada tahun 2015 telah menyebabkan kerugian ekonomi sebesar USD 16 milyar (World Bank Group, 2016). Tidak hanya kerugian materiil secara ekonomi, tetapi juga mempengaruhi kesehatan masyarakat (Watts \& Kobziar, 2012; Gaveau et al., 2014) dan mengganggu hubungan diplomatik Indonesia dengan negara tetangga, seperti Singapura dan Malaysia. Indonesia telah meratifikasi perjanjian ASEAN dalam pencemaran asap lintas batas (ASEAN Agreement on Transboundary Haze Pollution) pada tanggal 16 September 2014, sehingga berkewajiban untuk mencegah terjadi kebakaran dan asap yang dapat menimbulkan pencemaran asap di Asia Tenggara (Setyaki et al., 2013). Akan tetapi harapan tersebut tidak tercapai, karena pada kenyataannya tahun 2015 bencana kebakaran dan asap di berbagai tempat di Indonesia. Hingga Oktober 2015 dilaporkan luas kebakaran hutan dan lahan di Indonesia mencapai 2,6 juta ha (KLHK, 2015). Sementara laporan dari Sistem Kebakaran Hutan dan Lahan Sipongi, luas kebakaran hutan dan lahan tahun 2015 lebih rendah, seluas 261.060,44 ha (sipongi.menlhk.go.id).

Indikasi terjadinya kebakaran hutan dan lahan dapat diketahui dengan menggunakan teknologi Sistem Informasi Geografi (SIG) dan pemantauan titik panas (hotspot). Dengan menggunakan data titik api yang direkam secara kontinyu dan data spasial biofisik yang berpengaruh terhadap kejadian kebakaran hutan dan gambut, dapat dibuat peta kerawanan kebakaran di suatu daerah ((Samsuri, Jaya, \& Syaufina, 2012), (Widodo, 2014), (Mukti \& Rushayati, 2016)). Oleh karena itu, penelitian ini bertujuan untuk mengidentifikasi sebaran titik panas tahun 2014-2015 dan menganalisis tingkat kerawanan kebakaran gambut di Kabupaten Musi Banyuasin, Sumatera Selatan, serta faktor-faktor yang berpengaruh terhadap terjadinya kebakaran.

\section{METODOLOGI}

\section{A. Lokasi Penelitian}

Penelitian ini dilakukan di Kabupaten Musi Banyuasin, Provinsi Sumatera Selatan. Kabupaten ini merupakan salah satu kabupaten dengan intensitas dan frekuensi kebakaran hutan dan lahan tertinggi di Provinsi Sumatera Selatan (Anonim, 2016). Peta lokasi penelitian disajikan pada Gambar 1.

Kabupaten Musi Banyuasin memiliki area seluas $14.265,96 \mathrm{~km}^{2}$, ter- 
letak antara $1,3^{\circ}-4^{\circ} \mathrm{LU}$ dan $103^{\circ}-104^{\circ} 45^{\prime}$ BT. Kabupaten Musi Banyuasin di sebelah Utara berbatasan dengan Provinsi Jambi, di sebelah Barat dengan Kabupaten Musi Rawas dan di sebelah Timur dengan Kabupaten Banyuasin. Kondisi topografis Kabupaten Musi Banyuasin bervariasi dan dataran tinggi dan perbukitan di bagian Barat, dataran rendah di bagian Tengah dan Selatan, serta daerah rawa-rawa dan payau yang dipengaruhi oleh pasang surut di bagian Timur. Ketinggian daratan bervariasi antara 20-140 $\mathrm{m}$ di atas permukaan laut (BPS Musi Banyuasin, 2015).

Kabupaten ini terdiri atas 14 kecamatan, yaitu: Sanga Desa, Babat Toman, Batanghari Leko, Plakat Tinggi, Lawang Wetan, Sungai Keruh, Sekayu, Lais, Sungai Lilin, Keluang, Babat Supat, Bayung Lencir, Lalan, dan Tungkal Jaya. Diantara keempat belas kecamatan tersebut, Bayung Lencir memiliki kawasan terluas yaitu $4.847,0 \mathrm{~km}^{2}(33.98 \%$ dari total wilayah kabupaten). Kabupaten Musi Banyuasin memiliki daerah rawarawa (termasuk rawa gambut) yang cukup luas. Selain itu, kabupaten ini juga memiliki aliran sungai besar maupun kecil, seperti Sungai Musi, Sungai Batanghari Leko, dan Sungai Banyuasin (BPS Musi Banyuasin, 2015).

Kawasan hutan di area gambut di Kabupaten Musi Banyuasin berada di bawah kelola Kesatuan Pengelolaan Hutan Produksi (KPHP) Lalan Mangsang Mendis (LMM). KPHP ini disyahkan berdasarkan Keputusan Menteri Kehutanan Nomor SK.822/Menhut-II/2013 tentang Peta Kawasan Hutan Produksi Produksi Sumatera Selatan seluas 259.940 ha. KPHP ini terletak di Kecamatan Bayung Lencir, Kabupaten Musi Banyuasin, memiliki tiga resort, dengan blok tata hutan terdiri atas blok pemanfaatan hasil hutan kayu dari hutan alam, pemanfaatan hasil hutan kayu dari hutan tanaman, jasa lingkungan dan HHBK, serta pemberdayaan masyarakat.
Perizinan yang ada terdiri atas delapan Izin Usaha Pemanfaatan Hasil HutanHutan Tanaman (IUPHHK-HT), satu Izin Usaha Pemanfaatan Hasil Hutan Kayu Hutan Alam (IUPHHK-HA), satu Izin Usaha Penyerapan dan Penyimpanan Karbon dan dua Izin Usaha Hak Pengelolaan Hutan Desa (KPHP Lalan Mangsang Mendis, 2016).

\section{B. Metode \\ 1. Tahapan penelitian \\ a. Studi biofisik dan sebaran hotspot}

Kegiatan penelitian meliputi pengumpulan data primer dan sekunder. Pengumpulan data primer dilakukan dengan teknik survey ke lokasi penelitian. Data primer yang diambil terdiri atas data posisi geografis kebakaran, dan ground check kondisi lahan bekas terbakar khususnya di hutan dan lahan gambut di dalam KPHP Lalan Mangsang Mendis. Posisi geografis lokasi kebakaran direkam dengan GPS.

Kondisi vegetasi diamati pada tipe tutupan lahan rawa gambut, kebun karet dan kebun kelapa sawit yang terbakar. Kondisi vegetasi diamati di dalam petak contoh berukuran $20 \mathrm{~m}$ x $20 \mathrm{~m}$. Petak contoh diletakkan secara acak di beberapa tipe tutupan lahan bekas terbakar (hutan, kebun karet dan kebun sawit), dan hutan yang tidak terbakar. Pada masingmasing tutupan lahan dan hutan dibangun dua petak contoh, dengan jarak kedua petak adalah $100 \mathrm{~m}$. Pohon dengan diameter setinggi dada $\geq 10 \mathrm{~cm}$ diukur diameternya, dihitung dan dicatat jenisnya. Kondisi vegetasi menunjukkan tingkat kerusakan vegetasi akibat kebakaran. Tiga kriteria kerusakan vegetasi akibat kebakaran ditentukan sebagai berikut (Keeley, 2009):

- Kerusakan ringan: ditandai oleh tajuk pohon hijau, meskipun batangnya hangus. Sebagian tumbuhan masih bertahan hidup. Lebih dari $80 \%$ pohon yang rusak dapat bertahan hidup. 
- Kerusakan sedang: ditandai oleh sebagian tajuk pohon terbakar dan mati. Tumbuhan bawah sebagian besar $(80 \%)$ mati. Pohon yang dapat bertahan hidup sekitar 40-80\%.

- Kerusakan berat: ditandai oleh semua atau sebagian besar pohon terbakar dan tajuk mati. Tumbuhan bawah semua mati terbakar. Pohon yang bertahan hidup kurang dari $40 \%$.

Kedalaman gambut pada petak contoh diukur dengan menggunakan bor gambut Eijkelkamp. Tinggi muka air tanah gambut di petak contoh diukur dengan menggunakan pita meter (pengukuran sesaat). Dimensi kanal (lebar dan kedalaman) diukur dengan pita meter.

Pengumpulan data sekunder pendukung penelitian berupa peta spasial diperoleh dari beberapa Direktorat Jenderal (Ditjen) Kementerian Lingkungan Hidup dan Kehutanan (KLHK) dan instansi terkait, yaitu: sebaran titik panas (hotspot) dari data citra satelit NOAA18 tahun 2014 dan 2015 (Ditjen Pengendalian Perubahan Iklim - KLHK); data tutupan lahan tahun 2015, peta moratorium gambut dan hutan primer tahun 2015, dan peta Penunjukkan Kawasan Hutan tahun 2014 (Ditjen Planologi Kehutanan dan Tata Lingkungan KLHK); peta Kesatuan Hidrologis Gambut (KHG) Sumatera tahun 2016 (Ditjen Pengendalian Pencemaran dan Kerusakan Lingkungan - KLHK); peta Rupa Bumi Indonesia (RBI) skala 1:50.000 (Badan Informasi Geospasial, BIG); peta Tata Hutan KPHP Lalan Mangsang Mendis; peta Tata Hutan KPHP Meranti; dan peta Tata Batas PT. Global Alam Lestari (GAL). Peta-peta tersebut ditumpangsusunkan dan dianalisis dengan menggunakan piranti lunak (sotware) ArcMap ver.10.2.

Data curah hujan sepanjang tahun 2014 dan 2015 dari Stasiun Klimatologi terdekat, yaitu Bandara Sultan Thaha Jambi, diperoleh dari website weather underground (www.wunderground. com). Data demografi dan statistik diperoleh dari Badan Pusat Statistik Kabupaten Musi Banyuasin, Provinsi Sumatera Selatan.

\section{b. Studi aspek sosial dan kebijakan}

Wawancara semi terstruktur dengan informan kunci (key person) dari tiap pemangku kepentingan. Responden dipilih dengan metode purposive sampling yang mencirikan keterwakilan dari beberapa pemangku kepentingan. Pemangku kepentingan terdiri atas: Dinas Kehutanan tingkat provinsi (2 orang), Dinas Kehutanan tingkat Kabupaten (2 orang), KPHP Meranti (1 orang), KPHP Lalan Mangsang Mendis (1 orang), IUPHHKHTI Rimba Hutani Makmur (1 orang), IUPHHK-HTI Tripupa Jaya (1 orang), IUPHH-Pan-Rap Karbon Global Alam Lestari (1 orang), Hutan Desa Merang (1 orang), Hutan Desa Kepayang (1 orang), Kelompok Masyarakat Peduli Api (KMPA) Sinar Medak (1 orang), dan KMPA Bromo Sakti (1 orang). Informasi yang digali meliputi: (i) kejadian kebakaran, (ii) faktor pemicu dan penyebab kebakaran baik teknis maupun non-teknis, (iii) dampak kebakaran dan kabut asap, (iv) penanggulangan yang telah dilakukan, (iv) pencegahan yang telah dan sedang dilakukan, (v) kondisi setelah kebakaran pada tahun 2016, dan (vi) rencana atau program pemulihan ekosistem gambut bekas terbakar.

\section{Analisis data}

Analisis data spasial dilakukan melalui beberapa tahap kegiatan, yaitu: (i) Pengkelasan masing-masing variabel yang digunakan dalam penyusunan model; (ii) Penentuan bobot tiap faktor penyusun kerawanan kebakaran; (iii) Penghitungan nilai skor dan skor dugaan untuk masing-masing sub-faktor menggunakan formula (Samsuri et al., 2012); (iv) Penghitungan rescaling score atau 
skor skala, menurut formula (Arianti, Sinukaban, \& Jaya, 2007).

Skor sub-faktor $\left(\mathrm{X}_{\mathrm{i}}\right)=\left[\frac{0 \mathrm{i}}{\operatorname{ei} \mathrm{i}}\right] \times \frac{100}{\sum_{i=0}^{\mathrm{n}} \frac{0 !}{\theta i}}$

Jumlah hotspot yang diharapkan pada masing-masing sub-faktor $\left(\mathrm{E}_{\mathrm{i}}\right)=$ $\frac{T \approx F}{100}$

Score $R_{\text {out }}=$

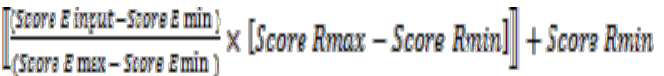
Keterangan:

$\mathrm{X}_{\mathrm{i}}=$ skor sub-faktor untuk masingmasing faktor

$\mathrm{O}_{\mathrm{i}}=$ jumlah hotspot yang ada pada masing-masing kelas

$\mathrm{E}_{\mathrm{i}}=$ jumlah hotspot yang diharapkan pada masing-masing sub-faktor

$\mathrm{T}=$ jumlah total hotspot

Score $R_{\text {out }}=$ nilai skor hasil rescaling

Score $E_{\text {input }}=$ nilai skor dugaan input

Score $E_{\min }=$ nilai minimal skor dugaan

Score $E_{\max }=$ nilai maksimal skor dugaan

Score $R_{\max }=$ nilai skor tertinggi hasil rescaling

Score $R_{\min }=$ nilai skor terendah hasil rescaling

Skor hasil rescalling pada masingmasing faktor akan digunakan untuk menghitung skor komposit dari beberapa faktor menggunakan metode Composite Mapping Analysis (CMA). Analisis regresi linier berganda dilakukan untuk menentukan bobot masing-masing faktor. Persamaan regresi ini menunjukkan hubungan antara kepadatan hotspot dugaan dengan skor komposit faktor-faktor penyusunnya. Bobot suatu faktor merupakan proporsi koefisien regresi dari faktor tersebut terhadap jumlah total seluruh koefisien regresi. Penghitungan nilai tingkat kerawanan tiap area (polygon) melibatkan skor hasil rescalling dan bobot masing-masing faktor, dan dilakukan dengan bantuan fasilitas field calculator pada software ArcGIS 10.

Nilai dugaan kepadatan hotspot yang dihasilkan untuk tiap area, mencerminkan tingkat kerawanan kebakaran, yang dalam penelitian ini dikelompokkan menjadi empat kelas, yaitu:

- sedikit rawan: jika nilai dugaan kepadatan hotspot $\mathrm{km}^{-2}<0,061$

- agak rawan: jika nilai dugaan kepadatan hotspot $\mathrm{km}^{-2}<0,121$

- rawan: jika nilai dugaan kepadatan hotspot $\mathrm{km}^{-2}<0,181$

- sangat rawan: jika nilai dugaan kepadatan hotspot $\mathrm{km}^{-2} \geq 0,181$.

Peta tingkat kerawanan selanjutnya ditumpangsusunkan dengan peta batas administrasi kecamatan sehingga dapat dianalisis tingkat kerawanan di tiap kecamatan dalam Kabupaten Musi Banyuasin.

Data curah hujan yang merupakan data sekunder dari hasil pengukuran (bukan data spasial), dianalisis secara terpisah menggunakan analisis regresi dan diuji signifikansinya menggunakan analisis varian, dengan menggunakan piranti lunak (software) SPSS IBM. Ver.21.

Data hasil wawancara dianalisis dengan metode kualitatif deskriptif. Data hasil studi pustaka berupa perencanaan dan kebijakan yang telah diputuskan di tingkat pemerintah daerah dilakukan dengan metode kualititatif deskriptif.

\section{HASIL DAN PEMBAHASAN}

\section{A. Hasil}

\section{Sebaran titik panas (hotspot)}

Peta sebaran hotspot Kabupaten Musi Banyuasin, Provinsi Sumatera Selatan dibuat berdasarkan data hotspot tahun 2014 dan 2015 (Gambar 1), yang 
bersumber dari Kementerian LHK. Hotspot di Kabupaten Musi Banyuasin tahun 2014 dan 2015 tercatat sejumlah 461 dan 596 hotspot.

Kebakaran di Kabupaten Musi Banyuasin terjadi secara berulang. Data penutupan lahan ditumpangsusunkan dengan data fungsi kawasan, peta perusahaan pemegang izin usaha pengelolaan hasil hutan, peta KHG dan peta moratorium untuk melihat sebaran hotspot di lokasi penelitian (Gambar 1). Pada Gambar 1 terlihat bahwa pada kawasan moratorium terdapat titik api dan kebakaran hutan dan lahan gambut pada tahun 2015, baik di APL dan di HP Jasa Lingkungan dan HP Wilayah Tertentu KPHP LMM.
Pada penelitian ini, hasil analisis regresi menunjukkan bahwa faktor yang mempengaruhi tingkat kerawanan kebakaran, yaitu (1) tipe tanah, (2) tipe penggunaan lahan, (3) fungsi kawasan, dan (4) jarak terhadap jalan. Pada Tabel 1 disajikan jumlah hotspot pada masingmasing sub-faktor, luas area masingmasing sub-faktor, kepadatan hotspot pada masing-masing sub-faktor, serta model regresi untuk masing-masing faktor.

Area lahan gambut di Kabupaten Musi Banyuasin seluas 374.360 ha (15,95\% dari total area Musi Banyuasin), sedangkan jumlah hotspot dan kepadatan hotspot pada lahan gambut lebih besar daripada di lahan mineral (Tabel 1).

\section{Jumlah dan kepadatan hotspot}

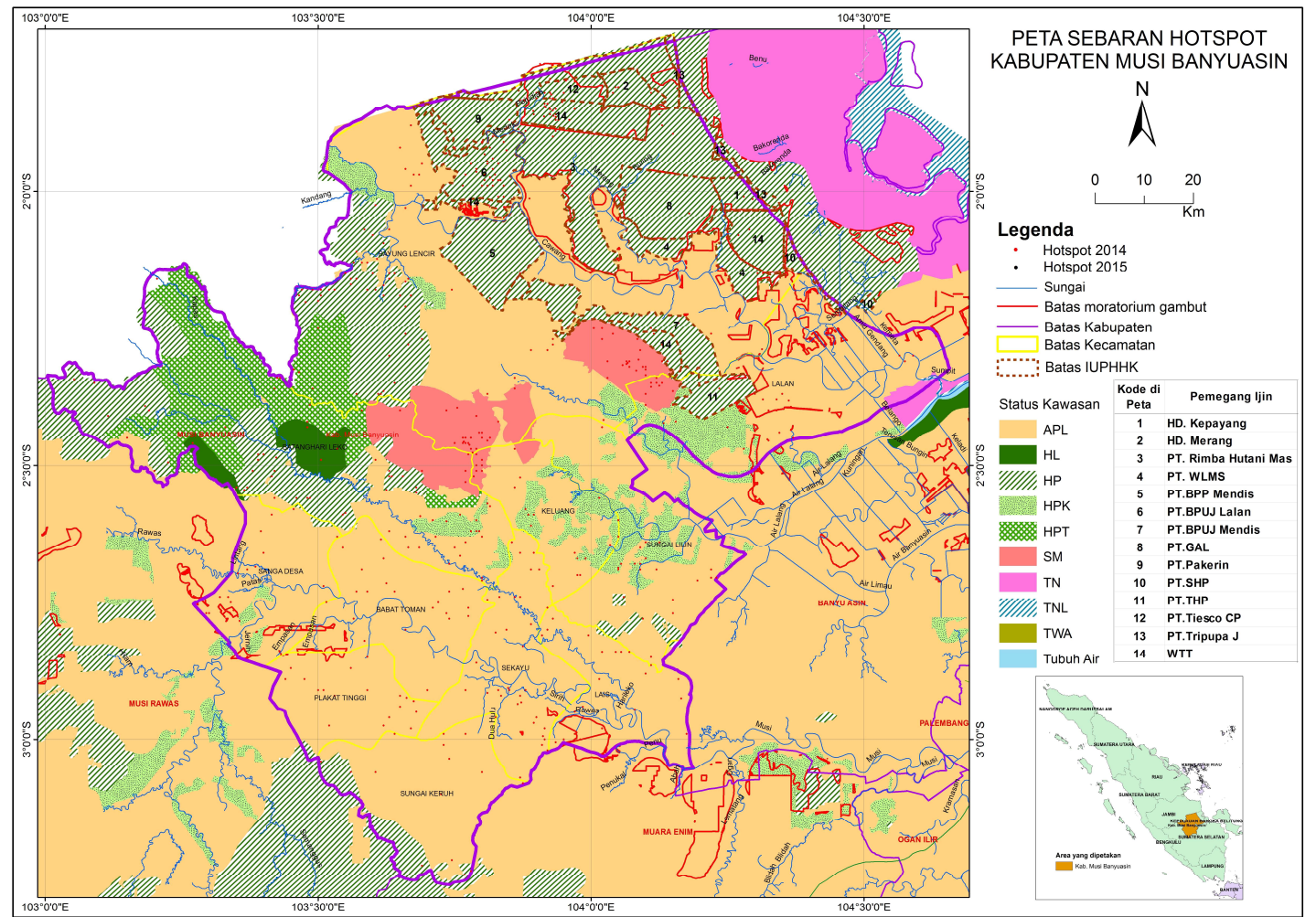

Gambar(Figure) 1. Peta sebaran titik panas tahun 2014-2015 di Kabupaten Musi Banyuasin, Provinsi Sumatera Selatan (Hotspot distribution year 2014-2015 in Musi Banyuasin district, South Sumatra province) 
Tabel (Table) 1. Kepadatan titik panas dan skor hasil re-scaling pada keempat faktor dan masing-masing sub-faktor (Hotspot density and score resulted from rescaling of fourth factors and each sub-factor)

\begin{tabular}{|c|c|c|c|c|c|}
\hline $\begin{array}{l}\text { Faktor \& Sub-faktor } \\
\text { (Factor \& Sub-factor) }\end{array}$ & $\mathrm{O}_{\mathrm{i}}$ & $\begin{array}{l}\text { Luas } \\
(\text { Area }) \\
\left(\mathrm{km}^{-2}\right)\end{array}$ & $\begin{array}{l}\text { Kepadatan } \\
(\text { Density) } \\
\left(\mathrm{HS} \mathrm{km}^{-2}\right)\end{array}$ & $\begin{array}{l}\text { Skor } \\
\text { (Score) } \\
\mathrm{R}_{\text {out }}\end{array}$ & $\begin{array}{l}\text { Model regresi tiap } \\
\text { faktor \& } \mathrm{R}^{2} \\
\text { (Regression model of } \\
\text { each factor \& } R^{2} \text { ) }\end{array}$ \\
\hline $\begin{array}{l}\text { 1.Tipe tanah(TT) (Soil type): } \\
\text { a. Gambut (Peat soil) } \\
\text { b. Non gambut (Mineral soil) }\end{array}$ & $\begin{array}{l}\mathbf{1 8 0} \\
138\end{array}$ & $\begin{array}{r}374.360 \\
1.972 .450\end{array}$ & $\begin{array}{l}0,048 \\
0,013\end{array}$ & $\begin{array}{r}100 \\
10\end{array}$ & $\begin{array}{l}\text { Утт }=40.412 \ln (\mathrm{x})+ \\
368.45 \\
\mathrm{R}^{2}=0,8029\end{array}$ \\
\hline $\begin{array}{l}\text { 2. Tutupan Lahan (TL) (Land cover): } \\
\text { a. Hutan Lahan Kering Sekunder } \\
\text { (Secondary dry-land) }\end{array}$ & 12 & $80.438,2$ & 0,015 & 27,1 & $\mathrm{Y}_{\mathrm{TL}}=4 \mathrm{E}^{-15} \mathrm{x}^{3}-3 \mathrm{E}^{-09} \mathrm{x}^{2}$ \\
\hline $\begin{array}{l}\text { b. Hutan Rawa Sekunder (Secondary } \\
\text { peats swamp forest) }\end{array}$ & 6 & $11.505,6$ & 0,052 & 11,5 & $\mathrm{R}^{2}=0,5376$ \\
\hline c. Hutan Tanaman (Plantation forest) & 8 & $70.775,9$ & 0,011 & 25,1 & \\
\hline d. Perkebunan (Estate) & 22 & 284.399 & 0,008 & 65,3 & \\
\hline $\begin{array}{l}\text { e. Pertanian Lahan Kering (Dry-land } \\
\text { agriculture) }\end{array}$ & 14 & $77.048,7$ & 0,018 & 26,4 & \\
\hline $\begin{array}{l}\text { f. Pertanian Lahan Kering Campur } \\
\text { (Dry-land mixed agriculture) }\end{array}$ & 77 & 491.329 & 0,016 & 100 & \\
\hline g. Belukar (Bushes) & 1 & $84.779,6$ & 0,001 & 28,0 & \\
\hline h. Belukar Rawa (Peatland bushes) & 81 & 134.992 & 0,060 & 37,9 & \\
\hline i. Sawah (Paddy field) & 1 & $29.874,3$ & 0,003 & 16,1 & \\
\hline j. $\quad$ Savana-Padang Rumput (Grassland) & 1 & $6.117,09$ & 0,016 & 10,0 & \\
\hline k. Permukiman (Settlement) & 1 & $25.985,1$ & 0,004 & 15,1 & \\
\hline 1. Tanah Terbuka (Open land) & 83 & 125.884 & 0,066 & 36,2 & \\
\hline m. Badan Air (Water body) & 9 & $10.468,9$ & 0,086 & 11,2 & \\
\hline $\begin{array}{l}\text { 3. Fungsi Kawasan (FK) (Forest } \\
\text { function): }\end{array}$ & & & & & $\mathrm{Y}_{\mathrm{FK}}=10.074 \mathrm{e}^{0.0054 \mathrm{x}}$ \\
\hline a. HP (Plantation forest) & 198 & 396.965 & 0,049 & 55,1 & $\mathrm{R}^{2}=0,3015$ \\
\hline b. HPT (Limited plantation forest) & 6 & 91.708 & 0,007 & 19,3 & \\
\hline c. HPK (Converted plantation forest) & 10 & 71.261 & 0,014 & 16,8 & \\
\hline d. HL (Protection forest) & 4 & 16.301 & 0,025 & 10,0 & \\
\hline e. SM (Nature reserve) & 20 & 67.515 & 0,030 & 16,4 & \\
\hline f. APL $[$ Other area (non-forest area) $]$ & 82 & 793.963 & 0.010 & 100 & \\
\hline $\begin{array}{l}\text { 4. Jarak terhadap jalan (JJ, km) } \\
\text { (Distance to road) }\end{array}$ & & & & & $\mathrm{Y}_{\mathrm{JJ}}=0.0195 \mathrm{e}^{-0.033 \mathrm{x}}$ \\
\hline a. 1 & 52 & 246.205 & 0,021 & 44,3 & $\mathrm{R}^{2}=0,4534$ \\
\hline b. 5 & 146 & 597.755 & 0,024 & 100 & \\
\hline c. 15 & 25 & 123.211 & 0,020 & 24,8 & \\
\hline d. 20 & 3 & 54.033 & 0,006 & 13,9 & \\
\hline e. 25 & 1 & 29.647 & 0,003 & 10,0 & \\
\hline f. 50 & 2 & 31.310 & 0,006 & 10,3 & \\
\hline
\end{tabular}

Keterangan (Remarks): $\mathrm{O}_{\mathrm{i}}=$ jumlah hotspot; HP = Hutan Produksi (Plantation Forest); HPT = Hutan Produksi Terbatas (Limited Plantation Forest); HPK = Hutan Produksi Konversi (Converted Plantation Forest); HL = Hutan Lindung (Protection Forest); SM = Suaka Margasatwa (Nature Reserve); APL = Area Penggunaan Lain (Other Land Use).

Berdasarkan faktor tipe tutupan lahan, jumlah hotspot terbanyak dijumpai pada lahan terbuka (83); sedangkan kepadatan hotspot tertinggi dijumpai pada pertanian lahan kering campur. Analisis regresi menunjukkan hubungan antara jumlah hotspot dengan tipe penggunaan lahan bersifat polynomial, dengan koefisien determinasi sedang $\left(\mathrm{R}^{2}=54 \%\right)$. 
Jarak suatu lokasi terhadap jalan memiliki hubungan negatif dengan jumlah hotspot. Jumlah hotspot terbanyak dijumpai pada jarak $5 \mathrm{~km}$ (146). Semakin jauh lokasi terhadap jalan, maka jumlah hotspot semakin rendah.

Berdasarkan faktor fungsi kawasan, hotspot paling banyak terdapat di hutan produksi (HP), dengan kepadatan 0,049 hotspot $\mathrm{km}^{-2}$. Meskipun area penggunaan lain (APL) menempati urutan kedua jumlah hotspot terbanyak (82). Kepadatan hotspot-nya relatif rendah dibandingkan dengan kawasan hutan $(0,010$ hotspot $\mathrm{km}^{-2}$ ).

Jumlah hotspot dalam kawasan hutan produksi KPHP LMM Mendis tahun 2014-2015 dan perusahaan pemegang izin usaha pengelolaan hutan disajikan pada Tabel 2. Jumlah total hotspot pada tahun 2015 tiga kali lebih banyak dibandingkan dengan jumlah hotspot pada tahun 2014. Hotspot terbanyak terdapat pada PT. RHM (104).

\section{Jumlah hotspot dan curah hujan}

Kejadian kebakaran hutan dan lahan berhubungan dengan curah hujan. Pada tahun 2015, terjadi kejadian cuaca ekstrim El Nino dan rendahnya hari hujan dan curah hujan tahunan. Data curah hujan tahun 2014-2015 dari stasiun klimatologi terdekat dihubungkan dengan jumlah hotspot pada tahun yang sama menunjukkan bahwa ada hubungan negatif antara jumlah curah hujan dengan jumlah hotspot, seperti disajikan pada Gambar 2.

Tabel (Table) 2. Jumlah hotspot tahun 2014-2015 pada kawasan hutan produksi KPHP Lalan Mangsang Mendis (Hotspot number in 2014-2015 in production forest area of Production Forest Management Unit of Lalan Mangsang Mendis)

\begin{tabular}{clcc}
\hline \multirow{2}{*}{ No. } & \multirow{2}{*}{ Nama IUPHHK (Concessionaire Holders) } & Jumlah hotspot (Hotspot number) \\
\cline { 3 - 4 } & & 2014 & 2015 \\
\hline 1 & HD. Kepayang (Village forest Kepayang) & 2 & 2 \\
2 & HD. Merang (Village forest Merang) & 5 & 15 \\
3 & PT. RHM & 11 & 104 \\
4 & PT. WLMS & 2 & 15 \\
5 & PT. BPP Mendis & 2 & 7 \\
6 & PT. BPUJ Lalan & 32 & 42 \\
7 & PT. BPUJ Mendis & 2 & 7 \\
8 & PT. GAL & 1 & 59 \\
9 & PT. Pakerin & 3 & 5 \\
10 & PT. SHP & 0 & 0 \\
11 & PT.THP & 1 & 13 \\
12 & PT.TCP & 10 & 18 \\
13 & PT.TPJ & 0 & 2 \\
14 & Wilayah Tertentu (WTT) (Certain Area) & 33 & 80 \\
\hline
\end{tabular}

Sumber (source): hotspot NOAA18/hotspot data (Ditjen PPI - KLHK, 2016) 


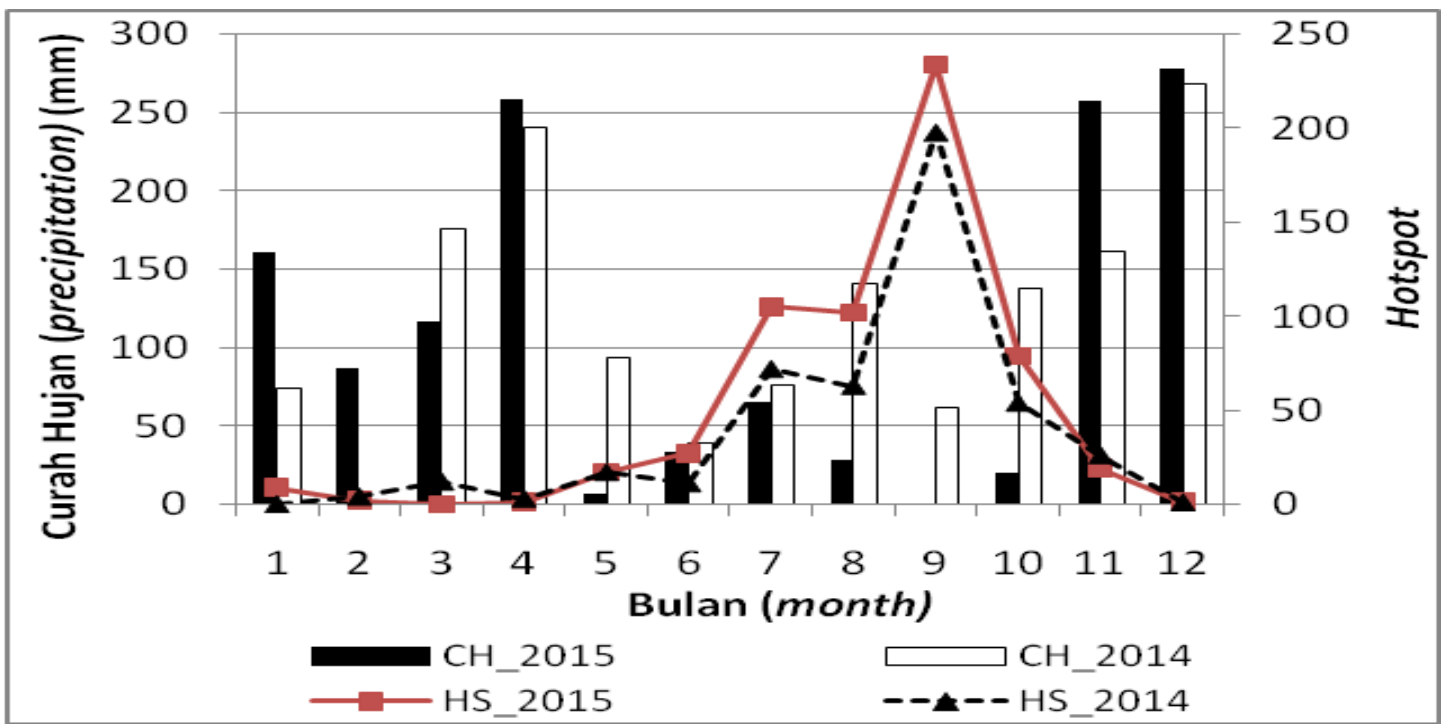

Keterangan (remarks): $\mathrm{CH}=$ curah hujan (precipitation), $\mathrm{HS}=$ hotspot

Gambar (Figure) 2. Hubungan curah hujan dengan jumlah hotspot tahun 2014-2015 (Precipitation and hotspots relation in 2014-2015).

Hotspot berkorelasi negatif dengan curah hujan. Model regresi linier: $\mathrm{Y}=$ $80,026-0,31 \mathrm{X}$, dengan koefisien determinasi $\mathrm{R}^{2}=20,6 \%$; dimana $\mathrm{Y}$ adalah jumlah hotspot, dan $\mathrm{X}$ adalah curah hujan. Meskipun koefisien determinasinya rendah, tetapi hasil ANOVA menunjukkan nilai $P \quad(p-$ value $)=0,026$, yang berarti curah hujan berpengaruh nyata terhadap jumlah hotspot. Koefisien determinasi yang rendah menunjukkan bahwa ada faktor lain yang juga mempengaruhi jumlah hotspot.

\section{Peta kerawanan kebakaran}

Analisis regresi linear berganda menghasilkan persamaan untuk pendugaan kepadatan hotspot (Y) sebagai berikut:

$\mathrm{Y}=-0.015+0.000511 \mathrm{X}_{1}+0.000226 \mathrm{X}_{2}$ $+0.000324 \mathrm{X}_{3}+0.000249 \mathrm{X}_{4}$ dimana: $X_{1}$ merupakan tipe tanah, $X_{2}$ status kawasan, $\mathrm{X}_{3}$ tutupan lahan, dan $\mathrm{X}_{4}$ jarak ke jalan. Berdasarkan persamaan regresi di atas, pembobotan terhadap keempat faktor adalah gambut/nongambut (40\%), tipe tutupan lahan (25\%), jarak terhadap jalan (20\%) dan status kawasan (15\%). Berdasarkan perumusan skor dan bobot untuk tiap faktor, telah dihasilkan peta tingkat kerawanan kebakaran seperti disajikan pada Gambar 3.

Hasil tabulasi luasan tiap tingkat kerawanan di tiap kecamatan disajikan pada Tabel 3. Kecamatan Bayung Lencir yang merupakan daerah dengan tipe tanah gambut cukup luas, memiliki tingkat sangat rawan yang paling luas, yaitu 155.244,5 ha. 


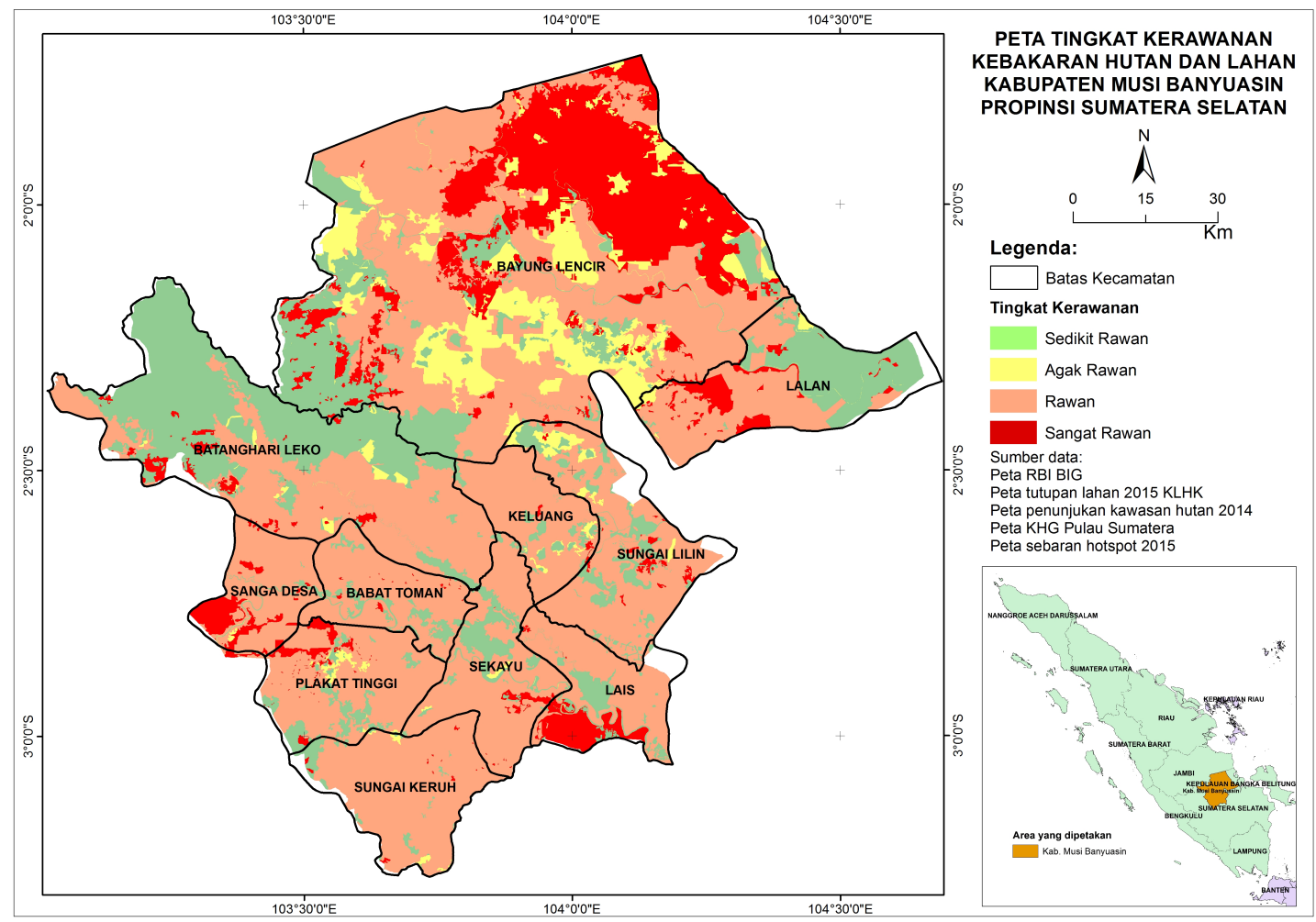

Gambar (Figure) 3. Peta kerawanan kebakaran hutan dan lahan Kabupaten Musi Banyuasin, Sumatera Selatan (Map of fire susceptibility on forest and land in Musi Banyuasin district, South Sumatra)

\section{B. Pembahasan}

\section{Faktor yang mempengaruhi jumlah dan kepadatan hotspot}

Ada berbagai faktor yang dapat mempengaruhi tingkat kerawanan kebakaran. Analisis regresi menunjukkan bahwa ada empat faktor yang berhubungan dengan titik hotspot dan kejadian kebakaran di Kabupaten Musi Banyuasin. Di tiap daerah, faktor yang mempengaruhi tingkat kebakaran berbeda-beda. Tingkat kerawanan kebakaran di Provinsi Kalimantan Tengah dipengaruhi oleh tutupan lahan, tipe tanah, sistem lahan, dan fungsi kawasan (Samsuri et al., 2012). Sedangkan tingkat kerawanan kebakaran di Provinsi Jambi dipengaruhi oleh jenis tanah (gambut/ non-gambut), tutupan lahan, ketinggian tempat, kelerengan, jarak dari desa, jarak dari sungai, jarak dari jalan dan jarak dari Daerah Operasi (Daops) Manggala Agni (Widodo, 2014).

\section{a. Faktor tipe tanah}

Analisis regresi menunjukkan bahwa tipe tanah berhubungan dengan hotspot secara logaritmik. Jumlah hotspot pada tipe tanah gambut lebih banyak daripada di tanah mineral. Padahal luas lahan gambut di Kabupaten Musi Banyuasin hanya 373.360 ha $(25,87 \%$ dari total luas area Kabupaten Musi Banyuasin). Kepadatan api di tanah gambut $0,048 \mathrm{HS} \mathrm{km}^{-2}$ (Tabel 1). 


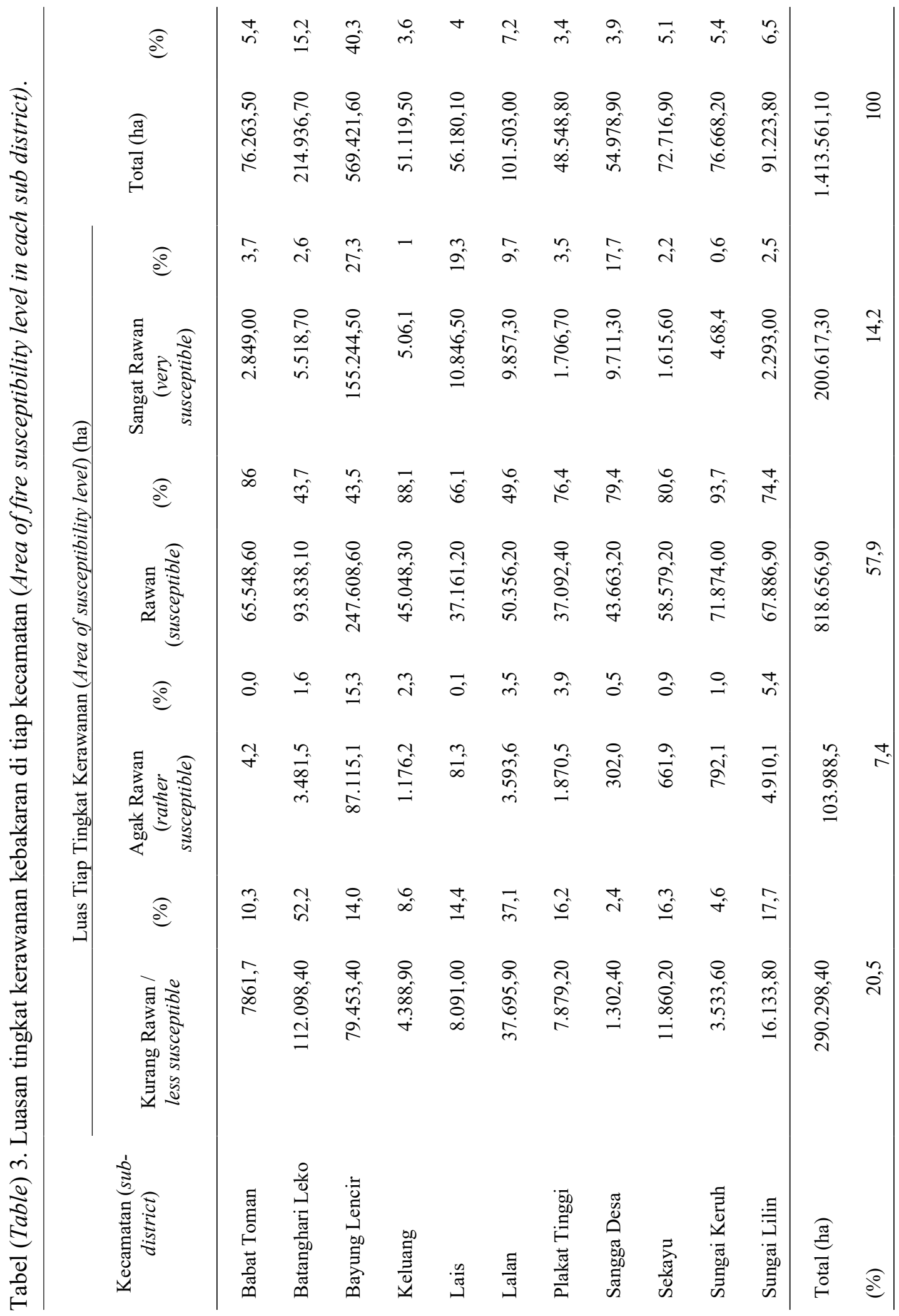


Pada kondisi alami, ekosistem gambut yang merupakan tumpukan bahan organik yang belum terlapuk, merupakan ekosistem yang jenuh air. Gambut dapat menyerap air 1 hingga 13 kali bobotnya (Dariah, Maftuah, \& Maswar, 2011). Akan tetapi, gambut yang telah ditebang vegetasinya dan dibangun drainase atau kanal sehingga air gambut terkuras, menyebabkan kondisi gambut berubah menjadi kering dan lapisan permukaan gambut menjadi lebih padat (subsiden) (Dariah et al., 2011), (Taufik et al., 2015). Hal ini menyebabkan gambut terdrainase menjadi rawan kebakaran (Syaufina, 2008), (Taufik et al., 2015), (Turetsky et al., 2015), (S. Page, 2016) (S. Page, 2016).

\section{b. Faktor tutupan lahan}

Berdasarkan tipe tutupan lahan, titik api banyak terdapat pada tanah terbuka, belukar rawa dan pertanian lahan kering campur. Tingginya kepadatan api pada (tepian) badan air berkaitan dengan kebiasaan masyarakat Kabupaten Musi Banyuasin yang melakukan penangkapan ikan di lebak dan lebung dengan cara membakar vegetasi (rasau dan pandan) di sekitar lebak dan lebung. Hal ini dilakukan karena dipercaya dapat meningkatkan peluang penangkapan ikan (Tim Penyusun, 2015), (Tarigan, Nugroho, Firman, \& Kunarso, 2016). Selain itu, tingginya intensitas pembalakan liar di kawasan hutan, merupakan salah satu pemicu terjadinya kebakaran di tepian badan air. Biasanya, pembalak membangun tenda atau 'camp' sementara di tepi kanal atau sungai. Faktor keteledoran manusia dapat memicu terjadinya kebakaran hutan (Tim Penyusun, 2015), (Tarigan et al., 2016).

\section{c. Faktor fungsi kawasan}

Analisis regresi faktor menunjukkan bahwa fungsi kawasan memiliki hubungan eksponensial dengan jumlah titik panas (hotspot), dengan koefisien determinasi sebesar 30,1\%. Jumlah dan kepadatan hotspot terbesar terdapat pada hutan produksi (HP).

Banyaknya titik api (hotspot) di kawasan HP berkaitan dengan faktor dari pengelolaan kawasan HTI di KPHP LMM, yaitu. pembangunan kanal pada hutan dan lahan gambut, baik di kawasan HTI, HGU, HD dan di APL. Pembangunan kanal pada HTI dimaksudkan sebagai sarana transportasi, batas kawasan, dan pengelolaan air. Akan tetapi pembangunan kanal tanpa memperhatikan kontur lahan, dapat menguras air gambut, yang pada akhirnya menyebabkan perubahan fisik gambut menjadi kering, sehingga gambut rentan terbakar. Padahal, pembangunan kanal dengan memperhatikan kontur lahan dan melakukan manajamen hidrologi sesuai dengan kaidah yang berlaku akan dapat membantu menjaga lingkungan dan ekosistem gambut (Sumarga, Hein, Hooijer, \& Vernimmen, 2016). Dalam penelitian ini, tidak diperoleh data spasial sebaran kanal pada KPHP LMM untuk dapat ditumpangsusunkan dengan data spasial lainnya. Masifnya kanal-kanal di kawasan KPHP LMM menyebabkan akses ke dalam kawasan menjadi mudah, sehingga membuka peluang bagi tindakan pelanggaran hukum, seperti pembalakan liar, pembakaran lahan dan perambahan hutan ((Zulfikhar, 2006), (Ananto \& Pasandaran, 2007), (Tim Penyusun, 2015), (Tarigan et al., 2016)).

Hasil pengamatan di dalam kawasan IUPHHK PT. RHM pada bulan Mei 2016, telah diupayakan pembangunan sekat kanal model sisir pada kanal tersier di area konsesi. Hal ini dilakukan sebagai suatu upaya untuk meningkatkan tinggi muka air tanah sehingga dapat membasahkan gambut yang kering (rewetting). Pada saat observasi, curah hujan relatif tinggi. Di beberapa lokasi bekas terbakar tampak genangan air yang cukup tinggi, sehingga dapat dikate- 
Hesti Lestari Tata, Budi Hadi Narendra dan Mawazin

gorikan sebagai banjir. Tinggi genangan air akibat kegiatan rewetting tidak lebih dari $10 \mathrm{~cm}$, jika lebih dari $10 \mathrm{~cm}$ dikategorikan sebagai banjir (Wilson, Blain, Couwenberg, Evans, Murdiyarso, Page, Renou-Wilson, Rieley, Sirin, et al., 2016).

Data tinggi muka air tanah secara rutin dicatat oleh petugas PT. RHM, namun data tersebut tidak dapat diakses oleh peneliti (Alex, komunikasi pribadi). Oleh karena itu, masih diperlukan kajian dan penelitian lebih lanjut mengenai dampak sekat kanal terhadap pengelolaan HTI, yang meliputi karakter gambut, dampak terhadap lingkungan (emisi $\mathrm{CO}_{2}$ dan subsiden), serta produktivitas lahan dan biomassa Acacia crassicarpa.

Tingginya jumlah hotspot tidak hanya terdapat pada area yang sudah mendapat izin kelola, tetapi juga pada Wilayah Tertentu (WTT) KPHP LMM. Persentase hotspot di WTT sebesar 21,7\% (Tabel 2). Menurut Lampiran Peraturan Dirjen Planologi Kehutanan No.P.5/VII-WP3H/2012, Wilayah Tertentu merupakan Blok Pemanfaatan yang berfungsi hutan produksi (HP), dan dapat dikelola secara mandiri atau bermitra dengan pengelola lain (Direktorat Jenderal Planologi Kehutanan, 2014). Banyaknya titik api di Wilayah Tertentu KPHP LMM disebabkan karena sebagian besar kawasan hutan tersebut tidak berhutan, dan menjadi area 'open access' yang rawan terhadap perambahan kawasan, serta kebakaran hutan dan lahan. Kegiatan rehabilitasi vegetasi sangat disarankan segera dilakukan, selain melakukan sekat kanal, agar ekosistem gambut dapat dipulihkan kembali.

Selain kanal-kanal yang dibangun secara sengaja untuk manajemen HTI, ada juga kanal yang dibangun secara liar oleh oknum-oknum yang tidak bertanggung jawab (dalam hal ini pembalak liar). Kanal liar dibangun sebagai akses pembalak liar untuk menuju ke kawasan hutan (Tim Penyusun, 2015), (Tarigan et al., 2016).

\section{d. Faktor jarak terhadap jalan}

Analisis regresi menunjukkan bahwa jarak terhadap jalan berhubungan secara eksponensial dengan titik panas (hotspot), dengan koefisien determinasi $\left(\mathrm{R}^{2}\right)=45,3 \%$ (Tabel 1). Jalan merupakan salah satu akses manusia menuju hutan dan lahan. Semakin dekat jarak terhadap jalan, semakin tinggi jumlah dan kepadatan titik api. Pada Tabel 1 terlihat bahwa jumlah dan kepadatan hotspot tertinggi terdapat pada lokasi yang berjarak $5 \mathrm{~km}$ terhadap jalan (masingmasing 146 dan 0,024 HS $\mathrm{km}^{-2}$ ), sedangkan jarak $1 \mathrm{~km}$ memiliki kepadatan hotspot sedikit lebih rendah $\left(0,021 \mathrm{HS} \mathrm{km}{ }^{-2}\right)$. Hal ini menunjukkan bahwa kejadian kebakaran kemungkinan besar disebabkan oleh ulah manusia, karena mudahnya akses. Hubungan positif antara kepadatan hotspot dengan jarak terhadap jalan juga dikemukakan oleh (Mapilata, Gandasasmita, \& Djajakirana, 2013) \& (Setyawan, 2015).

\section{Hubungan jumlah hotspot dan curah hujan}

Curah hujan yang rendah pada bulan September (tahun 2014 dan 2015) berkorelasi dengan tingginya jumlah hotspot pada bulan tersebut (Gambar 2) dan kejadian kebakaran hutan. Hal serupa juga dilaporkan oleh peneliti lain ((Hanifah, 2014), (Heriyanto, Syaufina, \& Effendi, 2014), (Tarigan et al., 2016)).

Gambut merupakan bahan organik yang pada musim kemarau dan kondisi kering merupakan bahan bakar yang mudah terbakar ((Syaufina, 2008), (Heriyanto et al., 2014), (Taufik et al., 2015)). Kondisi ini diperparah oleh kebiasaan masyarakat membuka kebun dan ladang dengan cara membakar vegetasi rumput, semak dan/atau belukar (Elysa, 2014). Meskipun dilakukan 
penjagaan terhadap api dan melakukan sekat bakar, tetapi pada lahan gambut yang kering api akan mudah menyebar ke bagian bawah gambut, yang menyebabkan kebakaran smoldering (Watts \& Kobziar, 2012; Elvidge et al., 2015); dan kejadian 'api loncat' akibat tiupan angin (Elvidge et al., 2015).

\section{Tingkat Kerawanan Kebakaran}

Peta tingkat kerawanan kebakaran Kabupaten Musi Banyuasin (Gambar 3), menunjukkan bahwa semua lahan gambut memiliki nilai tingkat kerawanan tinggi. Hal serupa juga dilaporkan oleh beberapa peneliti lain ((Samsuri et al., 2012), (Elysa, 2014), (Mapilata et al., 2013), (Widodo, 2014), (Tarigan et al., 2016)). Sebagian besar $(57,9 \%)$ lahan di Kabupaten Musi Banyuasin memiliki tingkat kerawanan "rawan" terhadap kebakaran. Kecamatan Bayung Lencir merupakan kecamatan dengan status "sangat rawan" yang paling luas, sedangkan Kecamatan Sungai Keruh merupakan kecamatan dengan persentase terbesar dengan status "rawan" kebakaran.

Tingkat kerawanan kebakaran pada lahan gambut diperparah akibat adanya kanal yang massif di berbagai titik, sehingga tanpa adanya upaya rewetting dan penyekatan kanal, maka kondisi gambut tidak akan basah kembali. Berbagai laporan menunjukkan bahwa penyekatan kanal dan rewetting dapat meningkatkan tinggi muka air tanah, sehingga dapat menurunkan emisi gas $\mathrm{CO}_{2}$, memperlambat subsidensi (Wösten, Clymans, Page, Rieley, \& Limin, 2008; Ritzema, Limin, Kusin, Jauhiainen, \& Wösten, 2014; Wilson et al., 2016; Jauhiainen, Page, \& Vasander, 2016); dan dapat mengurangi kejadian kebakaran (Evers, Yule, Padfield, O'Reilly, \& Varkkey, 2016; Taufik et al., 2015).

\section{Aspek regulasi dan peran serta masyarakat}

Kejadian kebakaran hutan dan lahan tahun 2015 di Kabupaten Musi Banyuasin menunjukkan bahwa kebakaran tidak semata disebabkan karena pengaruh iklim El Nino Southern Oscillation (ENSO), karena pada tahun 2014, saat tidak ada kejadian ENSO intensitas kebakaran relatif tinggi, dengan frekuensi kebakaran berulang terjadi di lokasi yang sama, seperti disajikan pada Gambar 1.

Meskipun telah ada peraturanperaturan larangan untuk penggunaan api untuk pembukaan lahan, seperti Peraturan Menteri Kehutan No. P.12/Menhut-II/ 2009 tentang Pengendalian Kebakaran Hutan. Tetapi pada kenyataan di lapangan, api tetap digunakan sebagai alat untuk membuka lahan dan api digunakan sebagai senjata pada konflik lahan. Alasan yang dikemukakan adalah api merupakan cara yang paling murah dan cepat untuk membuka lahan ((Dewi et al., 2015), (Purnomo et al., 2016), (Tata, Sakuntaladewi, Wibowo, Bastoni, \& Tampubolon, 2016), (Tata, H.L. et al., 2016)). Lahan yang telah terbakar selain siap ditanami, juga memiliki harga jual yang lebih tinggi. Menurut (Purnomo et al., 2016), studi di Riau menunjukkan bahwa kejadian kebakaran hutan dan lahan merupakan tindakan kriminal yang terorganisir. Tindakan kriminal yang terorganisir ini dilakukan oleh beberapa aktor, tidak hanya petani pengguna lahan, tetapi juga oleh cukong (spekulan tanah) dan korporasi.

Berdasarkan informasi yang diperoleh di lapangan, jual beli lahan di dalam dan sekitar Hutan Desa Merang telah berlangsung cukup lama. Meskipun patroli dan pengamanan hutan secara rutin telah dilakukan oleh petugas KPHP LMM. Upaya penegakan hukum terhadap oknum yang melakukan tindakan pembakaran lahan dan illegal logging telah dilakukan oleh polisi hutan, hingga Dinas 
Kehutanan Provinsi, bersama dengan aparat terkait, tetapi tidak memberikan efek jera.

Dalam Rencana Pengelolaan Hutan Jangka Pendek KPHP LMM, kegiatan yang berkaitan dengan upaya pencegahan kebakaran hutan dan lahan, terdiri atas:

(i) Penyelenggaraan perlindungan hutan, (ii) Patroli pengamanan hutan, dan (iii) Pengendalian kebakaran hutan. Peran para pihak telah diidentifikasi di dalam matriks ruang lingkup kegiatan KPHP LMM dengan para pemangku kepentingan untuk meningkatkan koordinasi dan sinergi. Pada praktiknya, masih perlu dilakukan peningkatan koordinasi di lapangan dengan pemangku kepentingan terkait dalam rangka pengamanan hutan dan pencegahan kebakaran hutan dan lahan gambut, mengingat kondisi di kawasan KPHP LMM banyak yang sudah 'open access'.

Dalam Peraturan Menteri Lingkungan Hidup dan Kehutanan Nomor P.12/Menlhk-II/2015 tentang Pembangunan Hutan Tanaman Industri, tidak dijelaskan secara detil mengenai kewajiban adanya sarana prasarana pengendalian kebakaran sebagai salah satu syarat dalam pembangunan HTI, kecuali pembangunan sekat bakar (pasal 1 butir 8). Selain itu, regulasi mengenai pengendalian kebakaran hutan diatur menurut Peraturan Menteri Kehutanan (Permenhut) nomor P.12/Menhut-II/2009. Selanjutnya, peraturan ini diperkuat dengan adanya Peraturan Menteri Lingkungan Hidup dan Kehutanan No. P.32/Menlhk/ Setjen/Kum.1/32016 tentang Pengendalian Kebakaran Hutan dan Lahan, sebagai norma, standar, kriteria dan pedoman atas perencanaan, pengorganisasian, pelaksanaan operasional, pengawasaan dan evaluasi dalam pelaksanaan usaha/ kegiatan/tindakan pengendalian kebakaran hutan dan lahan untuk para pihak terkait untuk menjamin efektivitas dan efisiensi pengendalian kebakaran hutan dan lahan. Aspek sanksi hukum tidak dijelaskan secara detil pada Peraturan tersebut.

Dalam kaitan dengan pengelolaan ekosistem gambut, menurut PP.57 tahun 2016 tentang Perlindungan dan Pengelolaan Ekosistem Gambut, masih mengatur tinggi muka air (TMA) tanah tidak lebih dari $40 \mathrm{~cm}$ pada fungsi budidaya. Salah satu tujuan pengaturan TMA ini adalah untuk menjaga kelembaban gambut, sehingga tidak rawan terhadap kebakaran. Para pemegang izin IUPHHK-HTI pulp dan kertas, seyogyanya memperhatikan regulasi ini, untuk menghindari bahaya kebakaran dan bencana kabut asap yang sewaktu-waktu dapat terjadi akibat kesalahan pengelolaan tata air/hidrologi gambut.

Permasalahan dalam pengelolaan $\mathrm{KPH}$, seperti illegal logging, kebakaran dan perambahan hutan, merupakan permasalahan yang jamak dihadapi oleh KPH (Ditjen Planologi Kehutanan, 2014), dan khususnya di KPHP LMM (Putro et al., 2016). Dampak deforestasi dan degradasi hutan (khususnya rawa gambut) terhadap meningkatnya resiko bencana kebakaran hutan dan lahan, telah disadari oleh Pemerintah Daerah Provinsi Sumatera Selatan. Pencegahan bencana menjadi salah satu target pembangunan seperti termaktub dalam Rencana Pembangunan Jangka Menengah Daerah (RPJMD) tahun 2013-2018 (Pemerintah Provinsi Sumatera Selatan, 2014), dengan sasaran sebagai berikut:

(i) Mengembangkan manajemen penanggulangan bencana melalui sistem peringatan dini, dan berkurangnya kerugian akibat bencana,

(ii) Berkurangnya kerugian akibat bencana antara lain ditandai dengan berukurangnya persentase kerugian akibat bencana. Pada tahun 2016, jumlah hotspot di Provinsi Sumatera Selatan berkurang secara signifikan. Hingga akhir November 2016, jumlah hotspot 165 titik api, dengan 
indikasi total luas kebakaran hutan dan lahan mencapai 266,5 ha (sipongi.menlhk.go.id).

(iii) Meningkatkan partisipasi masyarakat dalam pencegahan dan penanggulangan bencana kebakaran dan asap. Hal ini dapat dilakukan melalui pembentukan dan revitalisasi Kelompok Masyarakat Peduli Api (KMPA).

(iv) Meningkatkan kerjasama dan kemitraan dalam pencegahan dan penanggulangan bencana. Bentukbentuk kemitraan yang telah ada pada tahun 2016, misalnya: (a) Masyarakat dan Kelompok Tani di sekitar Hutan Desa Merang mendapatkan bantuan dana dari program kepedulian Corporate Sosial Responsibility (CSR) PT. RHM dalam melaksanakan patroli dan pengamanan hutan secara rutin; (b) Pembangunan sekat kanal di sekitar HD Kepayang yang rawan terhadap pembalakan liar, dilakukan bekerja sama dengan GIZ-Bioclime project dan PT. GAL. Pembangunan sekat kanal tersebut tidak hanya membawa dampak terhadap mitigasi bencana kebakaran dan perubahan iklim, tetapi juga meningkatkan adaptasi masyarakat melalui tersedianya alternatif pendapatan. Pembangunan sekat kanal meningkatkan populasi ikan air tawar, tangkapan ikan meningkat. Ikan-ikan dari kanal yang disekat tersebut tidak hanya dijual segar tetapi juga dikeringkan dan dijual ke pihak swasta di sekitar desa. Akan tetapi, jika permasalahan illegal logging tidak dapat dikendalikan, maka bangunan tidak permanen sekat kanal akan mudah dirusak oleh oknum sebagai akses masuk ke kawasan hutan.

Pemerintah Daerah Provinsi Sumatera Selatan merupakan salah satu provinsi yang memperhatikan pem- bangunan rendah emisi, dalam rangka mencapai target Rencana Aksi Daerah dalam penurunan Gas Emisi Rumah Kaca (RAD GRK). Dalam dokumen RAD GRK Provinsi Sumatera Selatan (BAPPEDA Sumatera Selatan, 2012) dicantumkan bahwa aksi sektor kehutanan dan lahan gambut yaitu difokuskan pada kegiatan yang secara langsung dan tidak langsung dengan pencegahan deforestasi, degradasi hutan, dan perubahan tutupan lahan. RAD GRK sektor kehutanan dan lahan gambut Provinsi Sumatera Selatan rencana atau program rehabilitasi hutan digunakan sebagai salah satu aksi mitigasi. Kegiatan pencegahan kebakaran hutan dan lahan tidak tertulis secara eksplisit, tetapi secara implisit termasuk di dalam RAD GRK, yaitu di dalam rencana aksi: (i) Program perlindungan hutan dan konservasi $\mathrm{SDH}$, dan (ii) Program rehabilitasi hutan dan lahan gambut. Akan tetapi belum ada realisasi program rehabilitasi hutan dan lahan gambut di KPHP LMM hingga akhir tahun 2016.

Sebagai respon dari kejadian kebakaran hutan dan lahan tahun 2015, Pemerintah Daerah Provinsi Sumatera Selatan juga telah mengesyahkan Peraturan Daerah (Perda) dan Peraturan Gubernur (Pergub) mengenai Pengendalian Kebakaran Hutan dan Lahan, yaitu Peraturan Gubernur Sumatera Selatan No. 11 tahun 2015 tentang Prosedur Tetap Pengendalian Kebakaran Hutan dan lahan; Peraturan Daerah Provinsi Sumatera Selatan No. 6 Tahun 2016 tentang Pengendalian Kebakaran Hutan dan/atau Lahan. Pemerintah Provinsi Sumatera Selatan menerapkan prinsip zero burning dalam pengelolaan lahan, dalam rangka low emission development dan green economic development yang tengah digalakkan oleh Gubernur Sumatera Selatan. 
Hesti Lestari Tata, Budi Hadi Narendra dan Mawazin

\section{KESIMPULAN DAN SARAN}

\section{A. Kesimpulan}

Kebakaran hutan dan lahan yang terjadi di Kabupaten Musi Banyuasin pada tahun 2015 lebih banyak terjadi di tanah gambut, dibandingkan tanah mineral. Titik panas lebih banyak terdapat di dalam kawasan hutan produksi.Tingkat kerawan kebakaran paling tinggi pada ekosistem gambut di Kabupaten Musi Banyuasin adalah di Kecamatan Bayung Lencir dengan tingkat "sangat rawan". Sebagian besar daerah Kabupaten Musi Banyuasin memiliki kerawanan terhadap kebakaran pada tingkat "rawan". Kebijakan mengenai pencegahan kebakaran gambut sudah tersedia, tetapi pelaksanaan di lapangan sulit diterapkan, karena (i) kurang tegasnya tindakan penegakan hukum bagi pelaku kebakaran hutan. (ii) Kurang tersedianya pengelolaan lahan gambut tanpa bakar yang efektif dan efisien.

\section{B. Saran}

Kegiatan pemulihan ekosistem gambut terdegradasi yang telah dilakukan oleh kelompok masyarakat, melalui pembangunan sekat kanal yang telah memberikan dampak nyata bagi pencegahan bahaya kebakaran, dan alternatif sumber pendapatan, selayaknya mendapatkan insentif. Kegiatan rehabilitasi vegetasi dapat dilakukan bersamaan dengan restorasi hidrologi. Ancaman pembalakan liar dan perambahan kawasan (oleh spekulan tanah) masih menjadi ancaman terbesar di kawasan KPHP LMM. Penegakan hukum masih perlu ditingkatkan bagi pelanggaran hukum. Implementasi kebijakan low emission development dan green economic development di tingkat tapak perlu segera dilaksanakan.

\section{UCAPAN TERIMA KASIH}

Penelitian ini dibiayai dari Daftar Isian Pelaksanaan Anggaran (DIPA) Anggaran Pendapatan Belanja Negara (APBN) Pusat Penelitian dan Pengembangan Hutan tahun 2016. Penulis mengucapkan terima kasih atas dukungan berbagai pihak, yaitu: Dinas Kehutanan Provinsi Sumatera Selatan, Dinas Kehutanan Kabupaten Musi Banyuasin, KPHP Lalan Mangsang Mendis, KPHP Meranti, PT. Rimba Hutan Makmur, PT. Tripupa Jaya, PT. Global Alam Lestari, GIZ-BIOCLIME project, LPHD Kepayang, LPHD Merang, KMPA Bromo Sakti, KMPA Sinar Medak, masyarakat Dusun Pancuran III dan Desa Kepayang. Penulis juga mengucapkan terima kasih kepada Robert Nainggolan, Sayuti, Priyatna, Rina Karokaro dan Wiji Suryahundaya yang telah membantu penelitian ini.

\section{DAFTAR PUSTAKA}

Ananto, E.E., \& Pasandaran, E. (2007). Pengelolaan Lahan Gambut di Provinsi Sumatera Selatan. In K. Suradisasatra, S. M. Pasaribu, B. Sayaka, A. Dariah, I. Las, Haryono, \& E. Pasandaran (Eds.), Membalik Kecenderungan Degradasi Sumber Daya Lahan dan Air (pp. 194-211). Bogor: IPB Press.

Anonim. (2016). Statistik Penyebaran Hotspot Tahun 2015 Provinsi Sumatera Selatan. Palembang.

Arianti, I., Sinukaban, N., \& Jaya, I.N.S. (2007). Modeling of forest and land fire risk level and zone using GIS in Kapuas Tengah sub basin, West Kalimantan Province. Jurnal Manajemen Hutan Tropika, 13(2).

BAPPEDA Sumatera Selatan. (2012). Dokumen Rencana Aksi Daerah Gas Rumah Kaca (RAD-GRK) Sumatera Selatan. Palembang: BAPPEDA Provinsi Sumatera Selatan. 
BBSDLP. (2013). Peta dan Rekomendasi Pengelolaan Lahan Gambut Terdegradasi di Sumatera. Bogor.

BPS Musi Banyuasin. (2015). Musi Banyuasin Dalam Angka (1st ed.). Sekayu: Badan Pusat Statistik Kabupaten Musi Banyuasin, Sumatera Selatan.

Cattau, M.E., Harrison, M.E., Shinyo, I., Tungau, S., Uriarte, M., \& DeFries, R. (2016). Sources of anthropogenic fire ignitions on the peat-swamp landscape in Kalimantan, Indonesia. Global Environmental Change, 39(November), 205-219. http://doi.org/10.1016/j.gloenvcha.2 016.05 .005

Dariah, A., Maftuah, E., \& Maswar. (2011). Karakteristik lahan gambut. In Badan Penelitian dan Pengembangan Pertanian (Ed.), Panduan Pengelolaan Berkelanjutan Lahan Gambut Terdegradasi (pp. 16-29). Jakarta: Badan Penelitian dan Pengembangan Pertanian. Kementerian Pertanian.

Dewi, S., Van Noordwijk, M., Dwiputra, A., Tata, H.L., Ekadinata, A., Galudra, G., \& Nakuntaladewi, N. Widayati, A. (2015). Peat and land clearing fires in Indonesia in 2015: Lessons for polycentric governance. Bogor.

Direktorat Jenderal Planologi Kehutanan. (2014). Strategi Pengembangan KPH dan Perubahan Struktur Kehutanan Indonesia (1st ed.). Jakarta: Direktorat Jenderal Planologi Kehutanan, Kementerian Lingkungan Hidup dan Kehutanan dan GIZ.

Ditjen Planologi Kehutanan. (2014). Strategi Pengembangan KPH dan Perubahan Struktur Kehutanan Indonesia. Jakarta: Ditjen Planologi Kementerian Lingkungan Hidup dan Kehutanan, dan GIZ.
Elvidge, C.D., Zhizhin, M., Hsu, F., Baugh, K., Khomarudin, M.R., Vetrita, Y., ... Hilman, D. (2015). Long-wave infrared identification of smoldering peat fires in Indonesia with nighttime Landsat data. Environmental Research Letters, 10(6), 65002. http://doi.org/10.1088/17489326/10/6/065002

Elysa, M.L. (2014). Spatial Decision Support System Untuk Pencegahan Kebakaran Hutan ( Studi Kasus : Kabupaten Kubu Raya ). Jurnal Sistem Dan Teknologi Informasi, 2(2), 1-6.

Evers, S., Yule, C., Padfield, R., O'Reilly, P., \& Varkkey, H. (2016). Keep Wetlands Wet: The Myth of Sustainable Development of Tropical Peatlands - Implications for Policies and Management. Global Change Biology, 1-16. http://doi.org/10.1111/gcb.13422

Gaveau, D.L.A., Salim, M.A., Hergoualc, K., Locatelli, B., Sloan, S., Wooster, M., ... Sheil, D. (2014). Major atmospheric emissions from peat fires in Southeast Asia during nondrought years: evidence from the 2013 Sumatran fires, 1-7. http://doi.org/10.1038/srep06112

Hanifah. (2014). Analisis hubungan curah hujan dengan distribusi kemunculan titik panas (Hotspot) untuk deteksi dini di Provinsi Kalimantan Timur. Institut Pertanian Bogor.

Heriyanto, E., Syaufina, L., \& Effendi, S. (2014). Perbandingan Indeks Fine Fuel Moisture Code (FFMC) dan Fire Weather Index (FWI) pada sistem peringkat bahaya kebakaran hutan/lahan luaran WRF dengan observasi (periode: Juni-Agustus 2013). Jurnal Meteorologi Dan Geofisika, 15(2), 119-127. 
Hesti Lestari Tata, Budi Hadi Narendra dan Mawazin

Jauhiainen, J., Page, S.E., \& Vasander, H. (2016). Greenhouse gas dynamics in degraded and restored tropical peatlands. Mires and Pear, 17, 1-12. http://doi.org/10.19189/MaP.2016.O MB.229

Keeley, J.E. (2009). Fire intensity, fire severity and burn severity: a brief review and suggested usage. International Journal of Wildland Fire, 18, 116-126.

KLHK. (2015). Sistem pemantauan kebakaran emisi karhutla 2015. Jakarta.

KPHP LalanMangsangMendis. (2016). Rencana Pengelolaan Hutan Jangka Pendek Kesatuan Pengelolaan Hutan Produksi Lalan Mangsang Mendis. Bayung Lencir.

Mapilata, E., Gandasasmita, K., \& Djajakirana, G. (2013). Analysis of Land and Forest Fires Hazard Zonation in Spatial Planning in Palangka Raya, Central Kalimantan. Globe, 15(2), 178-184.

Marlier, M.E., Defries, R., Pennington, D., \& Nelson, E. (2015). Future fire emissions associated with projected land use change in Sumatra. Global Change Biology, 21, 345-362. http://doi.org/10.1111/gcb.12691

Marlier, M.E., Defries, R.S., Kim, P.S., Koplitz, S.N., \& Jacob, D.J. (2015). Fire emissions and regional air quality impacts from fi res in oil palm, timber, and logging concessions in Indonesia. Environmental Research Letters, 10(8), 85005 . http://doi.org/10.1088/17489326/10/8/085005

Mukti, A., \& Rushayati, S.B. (2016). Mapping of Fire Vulnerability in Alas Purwo National Park. Procedia Environmental Sciences, 33, 290304. http://doi.org/10.1016/j.proenv.2016 .03 .080

Page, S. (2016). Memahami dinamika kebakaran lahan gambut di Indonesia. Lestari Journal, 1(1), 413.

Page, S. E., \& Hooijer, A. (2016). In the line of fire: the peatlands of Southeast Asia. Philosophical Transactions B, 371, 20150176.

Pemerintah Provinsi Sumatera Selatan. (2014). Rencana Pembangunan Jangka Menengah Daerah (RPJMD) Provinsi Sumatera Selatan tahun 2013-2018 (1st ed.). Palembang: Pemerintah Provinsi Sumatera Selatan.

Purnomo, H., Dewayani, A.A., Achdiawan, R., Ali, M., Komar, S., \& Okarda, B. (2016). Jaringan aktor dan regulasi kebakaran hutan dan lahan. Lestari Journal, 1(1), 55-73.

Putro, H.R., Yudiarti, Y., Ardisson, M., Nugroho, D., Yuningsih, L., Marpaung, T., ... Haasler, B. (2016). Laporan Rapat Koordinasi Kepala Kesatuan Pengelolaan Hutan (KPH) Provinsi Sumatera Selatan; Pembaharuan Peta Status Terkini KPH dan Quo Vadis. Palembang.

Ritzema, H., Limin, S., Kusin, K., Jauhiainen, J., \& Wösten, H. (2014). Catena Canal blocking strategies for hydrological restoration of degraded tropical peatlands in Central Kalimantan, Indonesia. Catena, 114, 11-20. http://doi.org/10.1016/j.catena.2013. 10.009

Samsuri, S., Jaya, I.N.S., \& Syaufina, L. (2012). Model Spasial Tingkat Kerawanan Kebakaran Hutan dan Lahan (Studi Kasus Propinsi Kalimantan Tengah) (Spatial Model of Land and Forest Fire Risk Index , 
Case Study in Central Kalimantan Province). Foresta Indonesia Journal of Forestry, (1), 12-18.

Setyaki, A., Rufaida, F., Ratnasari, R., Sugasri, A., Fauzi, A., Isbandi, S., ... Septiana, C. (2013). Buku ASEAN Agreement on Transboundary Haze Pollution.pdf. Jakarta: Kementerian Lingkungan Hidup.

Setyawan, D. (2015). Pemodelan spasial arah penyebaran kebakaran hutan dengan menggunakan penginderaan jauh dan sistem informasi geografis di Taman Nasional Baluran Kabupaten Situbondo Provinsi Jawa Timur Bulan Oktober tahun 2014. Universitas Muhammadiyah Surakarta.

Sumarga, E., Hein, L., Hooijer, A., \& Vernimmen, R. (2016). Hydrological and economic effects of oil palm cultivation in Indonesian peatlands. Ecology \& Society, 21(2).

Syaufina, L. (2008). Kebakaran Hutan dan Lahan di Indonesia: Perilaku Api, Penyebab, dan Dampak Kebakaran (1st ed.). Malang: Bayumedia Publishing.

Tarigan, M.L., Nugroho, D., Firman, B., \& Kunarso, A. (2016). Laporan dan Modul Teknis Pemutakhiran Peta Rawan Kebakaran Hutan dan Lahan di Provinsi Sumatera Selatan. Palembang.

Tata, H.L., van Noordwijk, M., Sakuntaladewi, N., Wibowo, L.R., Bastoni, Tampubolon, A., ... Widayati, A. (2016). Stopping haze when it rains: lessons learnt in 20 years of Alternatives-to-Slash-andBurn research in Indonesia. Nairobi.

Tata, H.L., Sakuntaladewi, N., Wibowo, L.R., Bastoni, \& Tampubolon, A. (2016). Managing peat fire risks in Tanjung Jabung Barat District,
Jambi, Indonesia. In W.R.W.A. et al. Khadir (Ed.), Proceeding 15th International Peat Conference 2016. Malaysian Peat Society. (pp. 381384). Kuching: Malaysian Peat Society.

Taufik, M., Setiawan, B.I., \& Lanen, Van, H.A.J. (2015). Agricultural and Forest Meteorology Modification of a fire drought index for tropical wetland ecosystems by including water table depth. Agricultural and Forest Meteorology, 203, 1-10. http://doi.org/10.1016/j.agrformet.20 14.12.006

Tim Penyusun. (2015). Profil Lokasi Kesatuan Hidrologis Gambut Merang-Kepayang. POKJA Revitalisasi Lahan Gambut Provinsi Sumatera Selatan. Palembang.

Turetsky, M.R., Benscoter, B., Page, S., Rein, G., Werf, G. R. Van Der, \& Watts, A. (2015). Global vulnerability of peatlands to fire and carbon loss. Nature Publishing Group, 8(1), 11-14. http://doi.org/10.1038/ngeo2325

Wahyunto, W., Nugroho, K., Ritung, S., \& Sulaeman, Y. (2014). Peta lahan gambut Indonesia: Metode pembuatan, tingkat keyakinan dan penggunaan. In A. Wihardjaka, E. Maftu'ah, Salwati, Husnain, \& F. Agus (Eds.), Prosiding Seminar Nasional dan Network Meeting Pengelolaan Berkelanjutan Lahan Gambut Terdegradasi untuk Mitigasi Emisi Karbon dan Peningkatan Nilai Ekonomi. (pp. 81-96). Balai Besar Litbang Sumberdaya Lahan Pertanian. Kementerian Pertanian.

Watts, A.C., \& Kobziar, L.N. (2012). Smoldering Combustion in Organic Soils: Peat and Muck Fires in the Southeastern U.S. Southern Fire Exchange. 
Hesti Lestari Tata, Budi Hadi Narendra dan Mawazin

Widodo, R.B. (2014). Pemodelan Spasial Resiko Kebakaran Hutan (Studi Kasus Provinsi Jambi, Sumatera). Jurnal Pembangunan Wilayah Dan Kota, 10(2), 127-138.

Wilson, S., Blain, D., Couwenberg, J., Evans, C.D., Murdiyarso, D., Page, S.E., ... Tuittila, E.S. (2016). Greenhouse gas emission factors associated with rewetting of organic soils. Mires and Peat, 17(4), 1-28.

Wilson, S., Blain, D., Couwenberg, J., Evans, C.D., Murdiyarso, D., Page, S.E., ... Tuittila, E.S. (2016). Greenhouse gas emission factors associated with rewetting of organic soils. Mires and Peat, 17(4), 1-28. http://doi.org/10.19189/MaP.2016.O MB.222

World Bank Group. (2016). The Cost of Fire. Indonesia Sustainable Landscapes Knowledge Note: 1, (February).
Wösten, J.H.M., Clymans, E., Page, S.E., Rieley, J.O., \& Limin, S.H. (2008). Peat - water interrelationships in a tropical peatland ecosystem in Southeast Asia. Catena, 73, 212224.

http://doi.org/10.1016/j.catena.2007. 07.010

Zulfikhar. (2006). Kebijakan Pengelolaan Kawasan Hutan Rawa Gambut dengan Pola KPH di Provinsi Sumatera Selatan. In A. Rimbawanto (Ed.), Prosiding Seminar Pengelolaan Hutan dan Lahan Rawa Secara Bijaksana dan Terpadu. (pp. 7-13). Bogor: Pusat Penelitian \& Pengembangan Hutan Tanaman. 